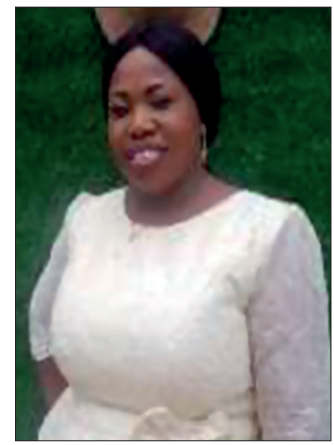

Helen Chukwudi Oribayo

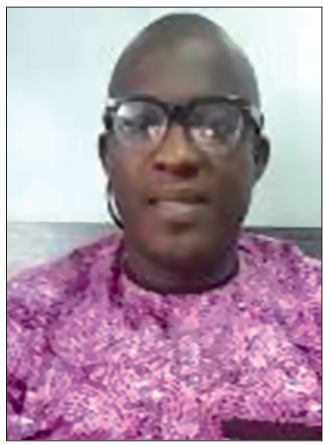

Ayodele Olalekan Shotunde

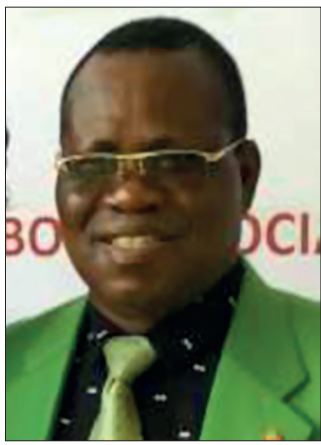

Godwin Ehi Azenabor

\title{
A Critical Reflection of Martins Buber's Philosophy of Education and Its Relevance in the New-State
}

\section{Abstract}

The aim of this essay is to examine the relevance of I and Thou through the lens of Martins Buber's philosophy of education. The fundamental problem is that the educational system in the new-states like Nigeria is in need of re-orientation. Owing to this, policy formulators and educational practitioners need to see education in relational terms with regards to its relevance, implementation and its methodology together with the ends which education wishes to serve to as a facilitator of societal development. The method of critical analysis is useful to facilitate the re-orientation exercise. Findings show that Buber's philosophy of education as embedded in the idea of I and Thou encourages interaction among individuals which are integral to the flourishing of positive relationship between the educational system and the community. Consequently, the paper attempts to unveil how this value position could impact positively on the Nigerian educational system in a bid to avert its decline. Buber's I-Thou (You) relationship opens avenue for encounter in which people could engage with each other fully through dialogue. The education is based on authentic relations between teachers and learners where knowledge that is not imposed by the teacher is the basis of true pedagogy. In Buber's idea of "I and Thou (You)", personal relation should tend beyond individualism and collectivism for the future generations. The knowledge of self should be first and foremost: learners must be taught to explore their two autonomous instincts: the originator and the communion. $\mathrm{Bu}$ - 
ber explains that the goal of the learner is to turn objective knowledge into active knowledge which helps in self actualization in the relational world.

Keywords: Buber's Philosophy of Education, Holistic Encounter, I and Thou, Nigerian Educational System.

\section{Introduction}

Since the inception of social and economic change whereby a human society is transformed from a pre-industrial to an industrial state coupled with the growth of large urban cities, particularly immediately after the end of Second World War, a philosophical theme, not wholly new, that was concerned about existence, human existence, the quality and conditions of the existing human individual started to occupy the front burner of scholarship. By the middle of nineteenth century, the main components of this theme popularly known as Existentialism had been established by a Dane, Søren Kierkegaard. Kierkegaard vehemently criticized Georg Wilhelm Friedrich Hegel's philosophy for his attempt to capture all of reality in his system of thought, yet in the process lost the most important element, namely existence (cf. Stumpf, 1983: 18; Omoregbe, 2006: 8 \& Unah, 2006: 28).

The relevant point from Kierkegaard's criticism is that existence implies human beings as individuals that are confronted with various issues of choice, decision making and commitment that define an essential self which are sought to be actualized. As a result, existence precedes essence. In contemporary pattern, existentialism is a reaction to the fact that the individual had over the centuries been relegated to the background by systems of thought, historical events and technologically driven societies. Even philosophy for the most part dealt with technical issues of metaphysics, epistemology and ethics in a general and objective manner that has little or no human touch as reflected in logical positivism. Evidence in the literature has shown that gradual and steady growth of industrialization has further dehumanized the western man who had been converted from subjects into objects by being harnessed to machines.

Furthermore, the traditional bastion of human hope, meaning and sense of worth as well as moral guidance has come under the scrutiny of rational and scientific thinking as reflected in Frederich Nietzsche's formal public announcement that for all its intent and purposes God is dead. He admonished that a new conception of human existence be built without taking God into consideration (Stumpf, 1983: 20-22 \& Omoregbe, 2004: 10). Nietzsche's statement has generated both argument for and against within and outside philosophy of religion context.

A number of existentialists such as Martin Heidegger, Jean Paul Sartre, Karl Jaspers and Albert Camus took a giant atheistic position in formulating their brand of existentialism. Scholars and researchers such as Søren Kierkegaard, 
Nicolas Berdiaev, Gabriel Marcel, Jacques Maritain and the Jewish thinkers turned to religion in order to rediscover what they believed has been missed by rational and scientific thinkers (Stumpf, 1983: 23 \& Omoregbe, 2004: 14). In the words of Curtis and Boultwood (1975: 18), the aforementioned group of scholars popularly known as 'theists' in the existentialists' movement has also been referred to as personalists or rational philosophers to distinguish them from the atheist group.

Irrespective of their standpoints, these two groups of existentialists agree that the traditional philosophy was too academic and far from life to have adequate meaning for human existence. In actual fact, they all are opposed to the objective, systematic and schematic tendencies that began with Rene Descartes and reach their apex in the Hegelian system (Curtis and Boultwood, 1975: 18; Omoregbe, 2006: 31 \& Unah, 2006: 10). They favour a more spontaneous mode of expression in the attempt to relate with the authentic concerns of individual existence in concrete terms. The personalists' agenda, including that of Buber's, aims at refocusing concentration on the objective world by considering the human person as the centre of their thought and has developed an outlook based on the individual.

In view of the above, the thought of personalists is more valuable for the philosophy of education. Personalists perceive the threat to the individual in the development of modern societies where individual has the tendency to be lost in the milling masses. In this direction, Buber said that "machines which were invented in order to serve men in their work were no longer like tools; an extension of man's arm, but man became that extension doing the bidding of the machines" (Curtis and Boultwood, 1975: 19; Omoregbe, 2006: 32 \& Unah, 2006: 13). Jaspers in turn with Buber stated that the tendency of the technological age is to transform nations into masses seemingly to participate in development while individuals were being alienated and dehumanized through mass education which made them blind and thoughtless in relation to their own existence. This tendency is entrenched in developed nations and taking roots in the new-states like Nigeria (Shotunde \& Irabor, 2018: 249).

Personalists also have it that the lack of existential thinking exist in nearly all the extant theories of knowledge. They readily accept the objective thinking of the scientists if it is limited to its proper sphere of scientific manipulations to the extent that man is not reduced to object of scientific investigation. In all these, personalists believed in a relational and human philosophy and education for the individual to realize his existence. Similarly, Wilhelm Dilthey perceived that the type of thought which is suitable to the human studies differs greatly from those applicable to the physical sciences. While the latter is concerned with the objective world, the former requires dealing with mental and spiritual life. Therefore, the only way to understand an individual is through the inside by reliving another person's experience 
and projecting ourselves into the person. In this direction, the real meeting and understanding takes place. Ordinarily in every aspect of human study an understanding is germane. Curtis and Boultwood quoting Dilthey to buttress the foregoing analysis argue that understanding is "a rediscovery of the $I$ in the Thou".

The point to note from the foregoing analysis is that education should generally be seen as a relation based enterprise in that the nature and the direction of the society determine the essence of its educational system. For instance, the philosophy of Nigerian educational system as formulated by National Policy on Education (2004 Edition) is based on the integration of the individual into a sound and effective citizen. In order to achieve this will, education has been directed to inculcate the following values: (i) the respect for the worth and digital on the individual; (ii) faith in man to make rational decision; (iii) moral and spiritual values in inter personal and human relation; (iv) shared responsibilities for the common good of the society and; (v) promotion of emotional, physical and psychological health for all learners.

To unveil the values of Buber's philosophy of education and its relevance in the new-states like Nigeria, this essay is divided into four parts. Part one situates the foundational issues within pre-industrial to an industrial stage of human society coupled with the growth of large urban cities, particularly immediately after the end of Second World War and the emergence of the existentialists' movement which birthed Buber's philosophical principles. Part two contextualises Buber's idea of "I and Thou" as central concepts for analyzing issues in the educational system. Part three offers the relevance of Buber's educational theory and implications for peaceful coexistence and political stability in the Nigerian educational system. Lastly but never the least, part four concludes with the consideration of the way our discussion in this paper gestures towards the importance of the sustainable character development and the benefit of relation issue that should be in tandem with every facets of the Nigerian society in the idea of I-You.

\section{Martins Buber's idea of "I and Thou"}

Martins Buber was born on February 8, 1878 in Vienna and died June 13, 1965 in Jerusalem. Buber was a German-Jewish religious philosopher and master of German prose style. Buber's philosophy was centred on the encounter or dialogue of man with other beings, particularly exemplified in the relation with other men but ultimately pointing to the relation with God. This thought reached its fullest dialogical expression in Ich und Du (i.e. I and Thou). With his idea of I and Thou, Buber proposed a humanistic alternative to the sharp differences between the science and objective dominated philosophies which tend to interpret human reality in mechanistic terms 
and idealistic philosophies which abstracted the human spirit from being entrenched in the real world of human community. In his book entitled, I and Thou Buber distinguishes between the two types of relationships for a proper understanding of human reality as I-it and I-You.

The "I-it" simply means is in relation with the world and other individuals functionally, manipulatively as things to be investigated and used. The world and people are for the individual like instruments for carrying out purposes. This type of relation is wrong as it has been a major cause of many problems in contemporary time as reflected in the educational systems of nations that see schooling as a production factory. In the "I-You" relationship, the individual encounters other persons and God as Thou (You) this involves interpersonal dialogue, an encounter which opens up the true depths of reality that engenders direct connection and a sense of unity for the individuals and the community with the necessary ethical underpinnings.

According to Buber (1969: 21), the positive aspect of education is when it is relational between the teacher and the learner on one hand and also between the educational system and the community on the other. In essence, the mutual rewarding education should generally be seen as a relation based enterprise in that the nature and the direction of the society determine the essence of its educational system.

In view of the above, Buber's I-Thou (You) relationship opens avenue for encounter in which people could engage with each other fully through dialogue. For Buber, all real life is encounter that is driven by dialogue which involves all kinds of relations to self, to others and to all forms of created beings. According to Buber (1958: 34), individuals and their community can only grow and develop once we have learned to live in true relation with others and recognize the possibilities of the space between us which makes self knowledge possible. The educational import of this is such that education is based on authentic relations between teachers and learners where knowledge that is not imposed by the teacher is the basis of true pedagogy.

Specifically, community is one of the main focuses of most educational systems. In Buber's idea of "I and Thou (You)", relation should tend beyond individualism and collectivism for the future generations. Buber sought to create a dialogical community which is a third way relation between the 'I-You' and collectivism which helps in the development of genuine community. This open inter-subjective dialogue is essential for holding society together and sustaining cultural creativity that helps in sustaining mutual relations with a living centre.

Be that as it may be, the building of an effective centre presupposes a foundational ethical outlook that binds people in true and mutual relations together. Therefore, the relevance of Buber's philosophy of education standpoint cannot be overemphasized. He believed in an educational system 
that is based on mutual relations-dialogue of inclusion at all levels and also an educational system that values the direct relation or appropriation of education in an emotional way by the community so as to make education the builder of the community with appropriate ethical system (i.e. character ethics).

\section{The Relevance of Buber's Educational theory to Nigerian Educational System}

Buber's theory of knowledge is entrenched in his metaphysical views of the philosophical idea of 'I-You'. This theory emphasizes a positive mutual and holistic encounter of two beings in their authentic existence. In Buber's opinion, a relation is central to human existence and reality. A person, according to Buber, is at all times engaged with the world in one form of these modes (i.e. I-You or I-it). The pattern employed to describe these modes of being is one of dialogue which expresses interpersonal nature of human reality.

In the words of Buber, knowledge of self should be first and foremost. Because it is only through the awareness of self that an individual can reach out to the other. For that reason, learners must be taught to explore their two autonomous instincts the originator and the communion. The former, which is the originator instinct, helps the learner about themselves - capacity building in relation to their world based on the societal ethical standard. While the latter, which is the communion instinct makes the learner to be conscious of the mutual and sharing which prepares the latter for true dialogue with 'Thou' and by extension, the community (cf. Yaron, 2002: 15). These instincts must go hand in hand thereby the absence of any could lead to alienation of the learner. In essence, Buber encourages the active role of learner in selecting and building his/her own knowledge as to be effective in his relations or encounter with people. In Buber's opinion, modern education that often gives priority to objective knowledge has little or no relevance.

At a deep level, Buber explains that the goal of the learner is to turn objective knowledge into active knowledge which helps in self actualization in the relational world. Therefore, the "nurturing of rational capacities" and not the "provision of opportunities for self expression and growth" through necessary are not the major functions of education. In this direction, for education to serve as an agent of change, it must free itself from the shadow of history moving the learning and his potential to the right and desirable direction in relational scheme of the community. This implies that sustenance and development of the community is germane in the goal of education.

Beside the National Curriculum Conference that took place in 1969, Nigeria has not deemed it fit to converge for national dialogue of inclusive and all 
encompassing about the nature, scope and the necessary changes that are germane to our educational system in view of the dynamics of the society. Instead of the aforementioned, Government officials do handpick stakeholders in an ad-hoc manner to discuss the presumed problems of education (Azenabor, 2018: 11). The result of this so called "kangaroo process" has not been effective in finding lasting solutions to educational problems thereby alienating the larger Nigerian society.

In his philosophy of education, Buber makes distinction between "to learn" and "to know". He perceives learning to be the "becoming character of the act of knowing" (Daniel, 1988: 51). In this direction, Buber sees knowledge in two folds, as in, knowledge of self and knowledge of reality. For him, an individual is in need of both experience and participate in the relational world characterized by pure dialogue. His theory of knowledge is premised on the primary reality of relation which truth is disclosed by knowing, loving and believing as a result of mutual and holistic encounter and other relationships of everyday life and not solely based on objective assessments. As such, coercion, indoctrination, propaganda are not proper sources of truth.

Recently, Nigerian society has been under great pressure of religious 'reawakening' from both Christians and Muslims who have established educational institutions at all levels directly and in few cases indirectly propagating their doctrines and belief systems. In this direction, pupils and students are coerced to attend religious gatherings and instructed to behave in accordance to religious ethical standard.

Just as other existentialists, Buber supported the study of the humanities and the liberal arts, language, history, geography, the social sciences and the natural sciences to the extent that they do not turn learners into objects in the classroom where learning is not relational. In the words of Omatseye (2004: 22), existentialists tend to encourage vocational education and engage in psychotherapy in an attempt to help learners regain their self-esteem or worth so as to assert himself if he must take cognizance of others who in turn recognize his personhood in the reciprocal relation. Other subjects included by Buber are moral education, aesthetic education, community and adult education.

Nevertheless, aforementioned subjects are adequately reflected in the Nigerian educational system but unfortunately are not given their appropriate places and emphasis. For instance, moral education to a large extent is seen as religious education. As a result, the Christian Religious Studies (CRS) and the Islamic Religious Studies (IRS) are emphasized. Meanwhile, the comprehensive syllabus for moral education is yet to emerge. The curriculum aims to train students for both human and intellectual development using such methods as logic, dialogue and critical meaning-making process. In religion and moral education, learners learn how to interpret traditions 
through images and symbols in music, art and literature and develop ways to understand their meanings and the environment which helps learners to build their personalities and character.

Moreover, aesthetic education helps in the creative imagination and sensitivity to the cultural laden values and realities of the communities. In essence, community and adult education connects individuals together as a community which promotes sharing certain ideals and enhancing the ability to set and achieve specific aims among members as well as encourage intercommunity dialogue (Akinkuotu \& Quadri, 2012: 91).

Specifically, teacher occupies the central position in Buber's educational theory and pedagogy. In the teaching learning process, Buber exalted the teacher learner relationship and dialogue. The teacher should take a formative, disciplinary and highly purposeful role. In addition to that, Buber sees teaching as the act of giving birth. He stressed further on 'teaching and deed' that he who teaches the tradition of his fellowman is regarded as though he has brought him to life (Akinkuotu \& Quadri, 2012: 92). The relevant point here is that within the Nigerian society, the respect for teachers has waned considerably while the governments have taken away some powers to instill discipline among students. In general, education has gradually failed to reflect the tradition and culture of Nigeria most especially in the private and religious owned schools. Coincidentally, Euro-Christian and Islamic cultures are on the rise, while Nigerian languages are on the verge of extinction (Olukoju, 2010: 138). Since there are large classes in government schools, personal relationships between teachers and students have reduced greatly resulting in low student academic performance and character development.

Buber sees the teacher as a healer of souls who occupies a central position in the lives of the students and the community. The teacher should stand as simple personal witness to the process of education in an active and loving manner showing concern for his students in full relations with them. The teacher as far from being perfect is also a human being with his/her strength and flaw who should embrace his functions which include counseling in an authentic manner. Therefore, the teacher should act as a 'filter and selector'. As a 'filter' his task is to refine the diverse messages arriving from his surrounding and as a 'selector' he must stand in contradiction to the old education characterized by a passive acceptance of tradition as well as the new education which are not proper and conducive to learning. The relationship between teachers and students is hierarchical as the teacher takes the major responsibility in exerting influences upon the learners as well as their growth and in the development of their potentialities. However, interference of the undue type and arbitrariness is not encouraged.

According to Buber (1958), a good teacher "educates when speaking as well as when silent, during the lessons as well as during recess, during 
occasional conversation, through his own behaviour provided he really exists and is really present". Teaching method is dominated by dialogue while other means that help the learner achieve their goals by the use of different techniques and activities are encouraged, Buber believed that relation in education is one of pure dialogue which stimulates inclusion. Inclusion in the sense that a capacity to develop a dual sensation between the teacher and the learner that has been described as experiencing oneself and simultaneously perceiving the other in its singularity (Avnon, 1998: 13).

In view of the above, one can come to know the other physically and spiritually. This has falsely been referred to as empathy. Buber (1947: 447) maintained that genuine education of character is genuine education for the community. Ethics entail engaging with the learners with their whole being in mutual relation. The educator educates from his own personal virtues and flaws through personal examples and according to circumstances and conditions. Ethics intermingles with character development that helps in the ability to make choices as a result of freedom and being able to face the consequent responsibilities which will help in discovering our true human nature. Lastly, it is imperative to underscore the fact that the introduction of values that lay claim to absolutism into character education is seen as an anomaly for ethical values are relative.

\section{Conclusion}

In this paper, we have examined the significance of Buber's philosophy of education and its relevance in the new-states like Nigeria. It is imperative to underscore the fact that Buber has not really developed a systematic pedagogy in his philosophy of education, but one thing that cannot be taken away from his philosophy is that he has punctured a clear path in transforming the relationship between teachers and students. Also, Buber laid the foundation for the role of true communication and language in educational practice which has led to authentic relations, care and reciprocation in educational matters.

In contemporary Nigeria, Buber's overall relevance as been made clear to all sphere of our educational practice is very visible and germane. Therefore, the Nigerian teachers at all levels need to be re-invigorated to begin to deal with students on a deeper personal level that is authentic so that students do not feel alienated or stranded in this era of large classes and increasing teacher-student ratio due to near collapse of infrastructure. Most especially in tertiary institution, this alienation has driven many students into nefarious activities such as cultism, crime, prostitution, serial absenteeism. Similarly, teachers are no longer seeing themselves as role models in the hue of Buber's philosophical education principles. The lack of mutual and engaging meeting 
between teachers and learners is one of the greatest challenges of the Nigerian educational system which has led to lower academic performances.

The absence of mutual understanding and dialogical relations between the system of education and the community has brought about the lack of interest in educational activities by parents. To many parents, payment of fees is what they owe the educational system and not any meaningful participation in remodeling education to meet societal needs. In this direction, education has serially failed to meet our challenges in infrastructural development, socio-economic and in building a crop of progressive leaders most especially in politics. With the improvement of the latter, the educational system will benefit immensely as a relation issue that should be in tandem with every facets of the Nigerian society in the idea of I-You rather than few cabal or government officials generating directive at intervals that pleases their political and economic interests.

\section{References}

Akinkuotu, Y. A. \& Quadri, Y. A. (2012) Martins Buber's Philosophical Idea of "I - Thou" and its Relevance to Modern Education in Nigeria. British Journal of Arts and Social Sciences, 8 (1), 87-94.

Avnon, D. (1998) Martins Buber: The Hidden Dialogue. Lanham: Rowman and Littlefield.

Buber, M. (1969) The Education of Character in the Human Encounter. New York: Hosps and Row.

Buber, M. (1958) I and Thou (2nd Edition). Edinburgh: T and T Clark Trans R.G. Smith.

Buber, M. (1948) Between Man and Man. London: Kegan Paul. Trans R.G. Smith.

Curtis, S. J. \& Boultwood, M. A. (1975) A Short History of Educational Ideas. London: University Tutorial Press.

Daniel, M. (1988) Martin Buber's Philosophy of Education. Dublin: Irish Academic Press.

Federal Republic of Nigeria (2004) National Policy on Education, Lagos: Federal Government Printers.

Olukoju, A. (2010) Christianity and Development of the Nigeria State. Anthony I. Asiwaju \& Ayodeji Olukoju (Eds.). Nigerian Peoples and Cultures. Ibadan: Davidson Press.

Omatseye, J. N. (2004) Educational Philosophy and African School. Benin City: Mindex Publications.

Omoregbe, J. I. (2006) A History of Western Philosophy Vol.3. Lagos: Joja Educational Research and Publishers.

Omoregbe, J. I. (2004) A Philosophical Looks At Religion. Lagos: Joja Educational Research and Publishers.

Stumpf, S. (1983) Philosophy: History and Problems (3rd Edition). New York: McGraw Hill.

Unah, J. I. (2006) Heidegger's Existentialism: An Essay on Applied Ontology. Lagos: Panaf Publishing Inc.

Yaron, K. (2002) Martin Buber: Prospects the Quarterly Review of Comparative Education. Paris: UNESCO: International Bureau of Education. 
Орібайо Гелен Чуквуді; Шотунде Айоделе Олалекан; Азенабор Годвін Ezi. Критичні розмірковування щодо філософії освіти Мартіна Бубера та її актуальності у нових державах

Мета цього есе - дослідити актуальність стосунку «Я і Ти» через призму філософії освіти Мартина Бубера. Фундаментальна проблема полягає у тому, що освітня система в таких нових державах, як Нігерія, потребує переорієнтації. У зв'язку з цим розробникам політики та практикам освіти необхідно бачити освіту у реляційному відношенні з точки зору їі актуальності, впровадження та методології, а також цілей, яким освіта хоче слугувати як фасилітатор суспільного розвитку. Метод критичного аналізу корисний для полегшення такої переорієнтації. Висновки показують, що філософія освіти, за Бубером, закладена в ідеї побудови стосунків за моделлю «Я і Ти», яка заохочує взаємодію між людьми і $є$ невід'ємною частиною процвітання позитивних відносин між освітньою системою та громадою. Отже, дослідження прагне розкрити, як ця ціннісна позиція може позитивно вплинути на нігерійську освітню систему, намагаючись запобігти їі занепаду. Стосунки за моделлю «Я і Ти», за Бубером, відкривають простір для зустрічі, в якій люди могли б повністю взаємодіяти один з одним шляхом діалогу. Освіта базується на автентичних відносинах між викладачами та учнями, де знання, які не нав'язуються вчителем, є основою справжньої педагогіки. Згідно моделі стосунків “Я і Ти" Бубера, міжособистісні стосунки для блага наступних поколінь мають підніматися над індивідуалізмом і колективізмом. Пізнання себе повинно бути першим і первинним: учнів слід навчити досліджувати свої два автономні інстинкти - ініціатора та учасника спілкування. Бубер пояснює, що мета учня - перетворити об'єктивні знання в активні знання, які допомагають йому самореалізуватися у реляційному світі.

Ключові слова: філософія освіти Бубера, голістична зустріч, Я і Ти, Нігерійська освітня система.

Орибайо Хелен Чуквуди; Шотунде Айоделе Олалекан; Азенабор Годвин Эги. Критические рассуждения о философии образования Мартина Бубера и ее актуальности в новых государствах

Цель этого эссе - исследовать актуальность отношения «Я и Ты» через призму философии образования Мартина Бубера. Фундаментальная проблема заключается в том, что образовательная система в таких новых государствах, как Нигерия, требует переориентации. В связи с этим разработчикам политики и практикам образования необходимо видеть образование в реляционном отношении с точки зрения его актуальности, внедрения и методологии, а также целей, которым образование хочет служить как фасилитатор общественного развития. Метод критического анализа полезен для облегчения такой переориентации. Выводы показывают, что философия образования, по Буберу, заложена в идее построения отношений по модели «Я и Ты», которая поощряет взаимодействие между людьми и является неотъемлемой частью процветания позитивных отношений между 
образовательной системой и сообществом. Таким образом, исследование стремится раскрыть, как эта ценностная позиция может положительно повлиять на нигерийскую образовательную систему, пытаясь предотвратить ее упадок. Отношения по модели «Я и Ты», по Буберу, открывают пространство для встречи, в которой люди могли бы полностью взаимодействовать друг с другом путем диалога. Образование базируется на аутентичных отношениях между преподавателями и учениками, где знания, которые не навязываются учителем, являются основой настоящей педагогики. Согласно модели отношений «Я и Ты» Бубера, межличностные отношения для блага будущих поколений должны подниматься над индивидуализмом и коллективизмом. Познание себя должно быть первым и первичным: учащихся следует научить исследовать свои два автономных инстинкта инициатора и участника общения. Бубер объясняет, что цель ученика - превратить объективные знания в активные знания, которые помогают ему самореализоваться в реляционному мире.

Ключевые слова: философия образования Бубера, холистическая встреча, Я и Ты, Нигерийская образовательная система.

Oribayo, Helen Chukwudi (M.A.) Department of Philosophy, University of Lagos, Nigeria. Helen Chukwudi ORIBAYO holds B.A. (Hons.), M.A. degrees from the University of Lagos, Nigeria, where she is currently working on her PhD. Her areas of specialization include: African Philosophy, Philosophy of Education and Ethics. She is currently an Administrative staff of the University of Lagos.

E-mail: hokobi@unilag.edu.ng

Орібайо, Гелен Чуквуді, магістр, кафедра філософії, Університет Лагоса, Нігерія, працює над дисертацією доктора наук. Напрями спеціалізації: африканська філософія, філософія освіти та етика.

E-mail: hokobi@unilag.edu.ng

Shotunde, Ayodele Olalekan (Ph.D.) (Corresponding Author) Department of Philosophy, University of Lagos, Nigeria. His area of competences and interests include Social and Political Philosophy (Western and African traditions), Philosophy of Education, Criminology and Security Studies, Conflict Resolution and Gender Studies. He is an E-Tutor of General African Studies and Introduction to Philosophy and Logic at the Distance Learning Institute, University of Lagos, Nigeria. Shotunde is a member of the Philosophical Association of Nigeria (PAN) and Associate member, Chartered Institute of Personnel Management of Nigeria (ACIPMN). Shotunde has staggering publications that have appeared in internationally indexed journals. He is a reviewer for a number of credible journals in his area of speciality.

E-mail: shotundeayo@gmail.com 
Шотунде, Айоделе Олалекан, доктор наук, кафедра філософії, Університет Лагоса, Нігерія, член Філософської асоціації Нігерії (ПАН). Область його інтересів: соціальна та політична філософія (західні та африканські традиції), філософія Росії, освіта, кримінологія та безпекові дослідження, вирішення конфліктів та гендерні дослідження. Він $є$ електронним репетитором загальноафриканської мови.

E-mail: shotundeayo@gmail.com

Azenabor, Godwin Ehi (Ph.D.) Department of Philosophy, University of Lagos, Nigeria. Godwin Ehi Azenabor holds B.A. (Hons.), M. Phil. and PhD degrees in African Philosophy from the University of Lagos, Nigeria, where he is currently a Professor. Apart from his specialization in African philosophy, his other areas of research and competence include: Philosophy of Education, Philosophy of Religion, Ethics and Metaphysics. He is the immediate past Head, Department of Philosophy. Azenabor is the author of several indexed and well-cited articles in both local and international journals, books and monographs. Azenabor won the 2007 University of Lagos best research Award for Arts and Humanities.

E-mail: gazenabor@unilag.edu.ng

Азенабор, Годвін Егі, доктор наук, професор, кафедра філософії, Університет Лагоса, Нігерія. Напрями наукових інтересів: африканська філософія, філософія освіти, філософія релігії, етика та метафізика. Азенабор отримав премію за мистецтво та гуманітарні науки університету Лагоса 2007 року.

E-mail: gazenabor@unilag.edu.ng 